\title{
Leisure as a Category of Culture, Philosophy and Recreation
}

\author{
Maria Zowisło
}

University School of Physical Education in Cracow, Poland

ABSTRACT

When we look at the very origins of human world, civilization in its history and prehistory, we can trace strong evidence of the archaic presence of leisure in human life. It seems striking and meaningful that in fact all that is human streams out from leisure. Leisure occurs to be an arch-human phenomenon. This paper addresses this multidimensional cultural presence and the sense and value of leisure conceived as a source of civilization, symbolic thought, social institutions, habits and practices. The cultural primordiality of leisure is evident when we take into consideration an aboriginal release from total preoccupation with only impulsive and instinctual survival activities that took place in the era of Homo habilis some 2 millions years ago. It is obvious that free time was a great achievement of these evolutionary forms of human beings when we reflect upon the earliest seeds of consciousness expressed in primitive pebble tools. These tools tell us about at least three important messages from our prehistory: that first man must have had some free time to think about given life-troubles and inventing implements; that primitive tools must have been a real help and means for hastening and unburdening a load of work and must have given in effect a small amount of discretionary time to avoid impulsive activity; and last, that primitive tools afterwards became the first material for imaginative aesthetic transformation and gave the first impulse for art. So art was the earliest non-compulsory and non-functional field of free activity and a borderline between the biological and cultural existence of infra-human and human species, the former centered completely and instinctively on just remaining alive and the latter disclosing outdistanced, free and reflective behavior. The next evolutionary steps in development of using free time were religion and philosophy. In religious acts with their ritual practices human beings made holy days of their holidays. Philosophical contemplation gave broad space for autonomous and autotelic thinking and self-fulfilling practices focused on human intellectual and moral selfrealization (semi-divine activity and happiness). But the most modern acceleration of exercising leisure is recreation understood as a differential area of physical culture, tourism, play and rest. Leisure occurs to be not only free time after obligatory activities bound up with biological determinants of life and with work are completed, it is also an important social factor (for instance, for the stratification of the levels or classes of society), an existential state of being, a phenomenon of rejuvenation, enjoyment, pastime, pleasure, distraction, indolence, idleness. Leisure appears at last a great challenge for humans to show their own specific and private attitude towards their lives and understanding their own position in the whole world. The authentic leisure is not void time, it is overfilled with creative acts confirming human freedom and capacity for transgressionvirtue, here and now, sentiments leisure, culture, philosophy, recreation 
An outstanding historian and philosopher of culture, Johan Huizinga believed games and plays were essential and archetypal elements of human world, i.e. the world of culture. Everything that is culture, that is, its fundamental institutions, such as language, myth and religion, art, science, law and morals can therefore be considered sub specie ludi, as deeply, genetically and structurally, rooted in arch-human playful tendencies, characterized by specific meaning. Play is a meaningful function of culture, but it is the sense of the senseless, because play is capricious, easy, free from the world's substantial determination, physical and biological ones, that could determine its structure, laws, and objectives possible for logical definition. Play is a 'superfluous surplus', superstructured by the human spirit over nature, and that is why it is arche of culture (Huizinga 1985, p. 15). A similar understanding of play as a non-functional function of culture, in conjunction with the philosophy of the game (in reference to the findings of Huizinga himself, but also to Wittgenstein's linguistic philosophy, or Gadamer's hermeneutics) is present in contemporary humanistic thought, including Roger Caillois, Bernard Suits, R. Scott Kretchmar and Michael Novak.

Exposed by a Dutch scientist, play's feature of independence from the substantial determinants of nature in the world (laws of nature) and in human (instincts) leads to further reflections, especially those associated with possible conditions of human's possibility of commencing free games with play. After all, life does not always allow a human to immerse in the joyful asylum of supra-logical acts of play. Most often - all in all - it determines humans to activities focused on preserving their own existence, what manifests on the levels of both as biological, and social bonds. Bonds like these include vegetative activities related to maintaining functions of the organism, as well as economic activities, which through professional efforts aim to ensure conditions for survival. Of course, this does not preclude understanding work as play, but such an approach is certainly accidental, not essential for the question of work. Thus, in order to play, one must have space free from life's obligations. It therefore seems that not just play, but freedom from the laws of nature, gradually gained in the long process of evolution of life on Earth by human beings, freedom used in different ways by those beings, was the first impulse toward the formation of culture. What was and remains space for this freedom in culture is free time - leisure. "The ethos of civilization and culture - as we read in one of the contemporary theorists of problems of leisure - finds its earliest seeds in the leisure which was first attained as evolution changed an animal into a human being" (Shivers 1981, p. 19). Contemporary anthropologists: Ernst Cassirer, Max Scheler, Arnold Gehlen, Helmuth Plessner or Hans Blumenberg express their opinions on anthropogenesis likewise. They emphasise that man has emerged from the animal world as a being handicapped by its drives (it was first Herder, who called man Mangelwesen), and compensated for its physical fragility by a culture that has become the 'second nature' of man. Culture is the fruit of liberation of paleoanthrops from the determination of nature and primordial identification with its forces. Human creative consciousness was born together with the achievement of a state of relative autonomy and distance to nature.

Leisure appears to be a condition much more primary and original for the existence of human spirit than mere play. Leisure makes it possible to play, while allowing at the same time other behaviours: sluggish, relaxed or meditative inactivity; sporting, recreational and tourist activity; celebration, art for art's sake; and finally (following Aristotle and Hegel), the most subtle of all human behaviours, i.e. philosophical contemplation. And while one can, as Johan Huizinga indicates, discern rudiments of play in all those human behaviours and attitudes, each of them separately is certainly idiogenetic and peculiar, and it would be wrong to apply a homogeneous pattern of ludi to understand the various meanings of these phenomena, supporting, in fact, the reductive strategy of hermeneutics. Without a doubt, however, the condition of emergence of the diversity of all these phenomena in culture, including multiple types of games and play, is the existence of leisure, in its emptiness and freedom capacious and open to any supra-logical and unnecessary activities, capricious and arbitrary, but also, as it sometimes happens, subject to limitations of sophisticated structures and practices of poiesis (creation) and theoria (cognition), limitations that are a result of human autonomy, freely shaped by the imagination of human spirit. 
The assumption of the cultural a priori value of leisure is explicite or implicite present in the discussions on the idea of leisure in such classic authors of the subject as Josef Pieper, Sebastian de Grazia, Joffre Dumazedier, Jay B. Nash or within younger researchers, for instance cited above Jay S. Shivers and others: Thomas Goodale, Geoffrey Godbey, Hayden Ramsey.

Shivers emphasises that leisure has emerged with the mastering by Homo habilis (about 2.5 million years ago) the early forms of making primitive tools - i.e. pebble tools. This could have happened only when the archaic Homo was no longer been focused solely on ad hoc activities related to survival and outmarched his present times by creating utility artefacts to accompany him for a longer period of time. Anthropologists note that Hominidae (already at the stage of Australopithecus preceding Homo habilis for at least one million years) used the primitive tools differently than apes (Pongidae), they did so more consciously, gradually creating tools for making tools, which indicates the beginnings of abstract and symbolic thinking, revealing the awareness of time (as well as thinking - as shown by Ernst Cassirer in his works on animal symbolicum - crossing simple reactions based on link between univocal stimulus and univocal instinctual response) (Cassirer 1944; Clark, Piggot 1965). Successive stages in the simultaneous progress of the use of leisure and creating culture were thousands of years of evolution and migration of Homo erectus (1.5 million - 100 thousand years B.C.), who domesticated fire and developed the aesthetics of the stone chopping-tools that goes beyond strict functional usefulness. Mastering fire contributed to breaking the natural cycle of day and night, light and darkness, wakefulness and sleep, enabling further progress in spreading a human artificial environment within the limits of nature. There was also a revolution in the culture of hunting, transporting, working up and consumption of meat, what consequently stimulated work specialization and social communication (meetings at the fire may be regarded as an archaic form of recreation). Fire, like nothing before, made human life easier, contributing to widening the sphere of time free from the natural and necessary behaviour (Shivers 1981, pp. 5-6).

The next steps in the evolution of culture and leisure have been made by representatives of Homo neanderthalensis. The Neanderthal era fossils (200-30 thousand years) indicate the rich use of colours, the first burials and a type of prehistoric hobby, which was collecting some minerals and crystals that must have seemed to those humans in some way unusual (Brézillon 1969). Paleoanthropologists also indicate the origins of imaginative thinking among the Neanderthals. Although this form of human seems to be a closed and extinct branch of evolution, there is no doubt that it affected the subsequent history of human culture. The end of the Neanderthal era fell on the beginnings of our factual progenitors, i.e. Homo sapiens. For thousands of years in the Upper Paleolithic Age, both forms coexisted with each other, probably exchanging more or less peacefully their experience (Reichholf 1990).

The Homo sapiens era that extends from about 70,000 B.C. until today, whose representative was a man of Cro-Magnon (Dordogne), is characterized by the extraordinary dynamism in the development of cave and utility art, dwellings technology, magic, shamanism, religious and afterlife images, social institutions, including the first forms of recreation. Shivers notes: "We have seen that throughout the development of human culture, some leisure has been present. Anthropologists, among other scientists devoted to the study of the development of humankind, have indicated that recreational experiences, in some form, were a direct outgrowth of the possession of leisure. There are indications that preliterate societies used leisure and recreational activity as both an instructional vehicle as well as a monument to human beings' aesthetic and creative tendencies" (Shivers 1981, p. 18). The socalled 'acrobats' rite, which was found in one of the caves in Sicily is dated to the Mesolithic Age, a transitional period between the Palaeolithic and Neolithic. More and more images of humans themselves (which had been rare pictures, always schematic and distorted in forms, in previous times) also gradually appear, both in hunting situations, and in ceremonial circumstances, often in dancing positions. Burials and presence of images related to the difficulty of everyday life and rituals of the sacred time in the rock art indicate a progressive complication in the experience and use of time of prehistoric man. Intensity and splendour of the magical and shamanistic rites (Eliade 1978; Eliade 
1994; Trzciński 1996) became the first strong impulse to the division of time into the sacred (sacrum) and secular ones (profanum) (Eliade 1957). Holy time was experienced as a distinctive, exalted time, after all it was honoured by the contact with the world of ancestors, the dead, demons, and gods. And while because of its magical and shamanistic provenance it still seemed to be ultimately at the service of people (ensuring success at hunting or restoring the shattered equilibrium of life and cosmic space), the holy time gradually took on features of freedom and independence from the usual work, and the man was more and more eager for the joyful experience because of its relaxing and recreational properties (in terms of both cosmic and personal dimension) (Eliade 1974).

The Neolithic Revolution, which occurred in the Middle East about $10^{\text {th }}$ millennium B.C., has brought further complexity and diversification to the human experience of time. Rising settlements, cities, and great civilizations became the nucleus for the emergence of social stratification. For the first time a social stratum of people appeared, and the class of rulers and priests can be defined as a leisureclass, enjoying absolute freedom from work and full access to the privileges of leisure. It is impossible to refer here to all the major achievements of the civilization of Sumer, Akkad, Babylon, Egypt and Israel (the latter in the lore of the Bible, distinguishes sacred time as rooted in the divine work of creation of the world, completed with six days of creative work and the seventh day of rest). Let us mention only what is most important for the European experience of leisure.

The period of 800-200 B.C. was a very creative period in many civilizations of the world. Karl Jaspers called it an axial period, Achsenzeit (Axial Age, Pivotal Period), noting that at that time, philosophy and the great doctrines of religion filled with philosophical spirit had been formed: Confucianism, Taoism, Buddhism, prophetic Judaism, the wisdom of Upanishads. All of these trends have produced a solid foundation for the development of humanism, freedom, and moral improvement ethos (Jaspers 1949). Ernst Cassirer emphasised that at that time there was a radical change in religious-mythical ideas - religion had entered into a relationship with ethics, offering humans a realm of ideals different from archaic magical impact on the external world. New models were focused this time on the formation of the soul, an inner human personality (Cassirer 1944).

The axial period is also particularly important for the evolution of ideas of leisure. In Chinese Taoism, the principle of non-action, $w u$ wei, has been shaped, associated with the ideal of virtue and the power of man, anchored in the affirmation of nature and natural behaviour. In many ways it is similar to the Greek idea of leisure - schole. In the Occidental World it was Greek culture that created the original awareness of the value of leisure. This is connected with the emergence of Greek philosophy and sporting agon, which resulted in a peculiar alliance with the holistic model of paideia and ethos of eudaimonia, education and personal self-fulfilment. This alliance has become paradigmatic for the contemporary, complex, multidimensional understanding of recreation as a way of being human in the space of leisure. Let us therefore devote some attention to it.

For contemporary scholars the essence of the Greek philosophical understanding of leisure is best expressed in the work of Aristotle. Leisure was the very philosophy. Schole, inactivity, non-action did not mean laziness and idleness, but an extraordinary intensification of what is most human reason, logos, noesis. Time of schole was - and that is the form we find in Aristotle - filled with philosophical contemplation of the highest, divine principles of being. It was the cultivation of the divinity in man. Community of schole and theoria was set in non-utilitarianism, disinterestedness of their goals - those were fields of life cultivated for their own sake, the areas free from worries, drudgery of everyday life, with its work and family as well as social responsibilities. Freedom, autotelism, self-realization, ceremony of human, intellectual, personal and moral perfection - these values determine the nature of the Greek schole (Arendt 1958, Pieper 1961, Goodale, Godbey 1995, pp. 1-12, Grazia 1964).

In accordance with numerous observations made in Politics and Nicomachean Ethics leisure must be filled not with play, but with 'serious efforts', entelechia, i.e. actions intended to upgrade human potency, maturity. Entertainment satisfies utilitarian function, is necessary for relaxation and 
renewal of human forces after work, they are thus harnessed - as Plato expressed it in his Leges - in the economic cycle of work and rest. However, if one indulges in entertainment moderately, it can provide, in addition to relaxation, a sort of playful, ludic, pleasure peculiar for them, which also has a corresponding virtue eutarpelia, i.e. 'humour and smoothness' (golden measure between mockery and sullenness) (Ramsay 2005, pp. 9-14). The education of youth for proper functioning in the role of a free citizen should include, inter alia, according to Aristotle, gymnastics and music (as it was previously expressed by Plato in his Republic). Music, however, is more noble compared to gymnastics that trains for bravery, it is worthy of itself, it produces a purely aesthetic pleasure with its beauty. It also stimulates the moral state of the soul, evoking appropriate moods and intentions by its rhythms and tones.

The classical Greek cult of beauty was expressed in the union of the values of soul and body. The beauty of the body is athletic beauty, beauty of the soul is moral beauty. That union was inscribed by Plato in the ideal of kalokagathia. Beauty and goodness of man are equivalent, they point to virtue, bravery, greatness - megalopsychia (Aristotle). These highly individualistic and perfectionist ideals could have flourished only under the sun of Hellas, which gave the world philosophy and sport.

Contemporary meanings, with which man fills his leisure, often refer to the ideals of Greeks (for such researchers as Pieper and de Grazia, Hellenic classicism is a model par excellence for leisure properly understood and realised). That is why modern man in his leisure likes to be a little of a philosopher and an athlete, combining moral perfectionism, hedonic as well as ludic intentions and actions in the complex niche of recreation, treating them all as the values necessary for building happiness, wholeness, healthiness and even holiness in his personality and life offered to him by his fate. The task of the humanists is to evoke this complex, classical model of human self-fulfilment in his leisure. In the so-called post-industrial era, leisure, widely available, is subject to deceptive techniques of bio-power, becoming the market of recreation industry. It depends on man's selfknowledge and courage, whether his freedom, an indispensable quality of his leisure, will not be alienated. Leisure appears at last to be a great challenge for humans to show their own specific and private attitude towards their lives and understanding their own position in the whole world. The authentic leisure is not void time, it is overfilled with creative acts confirming human freedom and capacity for transgression. (Kosiewicz 2010, pp. 166-191).

\section{REFERENCES}

Arendt, H. (1958). The Human Condition. Chicago: University of Chicago Press.

Brézillon, M. (1969). Dictionnaire de la préhistoire. Paris: Libraire Larousse.

Cassirer, E. (1923-1929). Philosophie der symbolischen Formen. Teile I-III. Berlin: Bruno Cassirer Verlag.

Cassirer, E. (1944). An Essay on Man. New Haven: Yale University Press.

Clark, G., Piggot, S. (1965). Prehistoric Societes. London: Hutchinson and Co. Ltd.

Eliade, M. (1974). The Myth of Eternal Return or, Cosmos and History. Princeton: Princeton University Press.

Eliade, M. (1994). Shamanism: Archaic Techniques of Ecstasy. London: Routledge and Kegan Paul.

Eliade, M. (1957). Das Heilige und das Profane. Vom Wesen des Religiösen. Hamburg: Rowohlt.

Eliade, M. (1978). History of Religious Ideas. Vol. I. From the Stone Age to the Eleusinian Mysteries. Chicago: University of Chicago Press.

Goodale, Th., Godbey, G. (1995). The Evolution of Leisure: Historical and Philosophical Perspectives. State College, PA: Venture Publishing.

Grazia, S. de (1964). Of Time, Work and Leisure. Garden City, NY: Doubleday \& Company, Inc.

Huizinga, J. (2008). Homo ludens. London: Routledge.

Jaspers, K. (1949). Vom Ursprung und Ziel der Geschichte. München: Piper Verlag.

Kosiewicz, J. (2010). Free Time from the Perspective of Ontology and Epistemology of Time. In J. Kosiewicz, Sport and Philosophy. From Methodology to Ethics (pp. 166-191). Warszawa: Wydawnictwo BK.

Pieper, J. (1961). Leisure: The Basis of Culture. New York: Pantheon Books.

Ramsay, H. (2005). Reclaiming Leisure: Art, Sport and Philosophy. New York: Palgrave Macmillan. 
Reichholf, J. H. (1990). Das Rätsel der menschwerdung - Die Entstehung des Menschen im Wechselspiel mit der Natur. München: Deutscher Taschenbuch Verlag GmbH\& Co. KG.

Shivers, J. S. (1981). Leisure and Recreation Concepts. A Critical Analysis. Boston: Allyn and Bacon, Inc.

Trzciński, Ł. (1996). Człowiek pierwotny i jego wierzenia. Kraków: PAN

AUTHOR'S ADDRESS: Maria Zowisło

ul. Krasickiego 14/8

30-503 Kraków, Polska

Email: mzowislo@op.pl 